\title{
A love of family medicine that took root in the rugged Canadian Shield
}

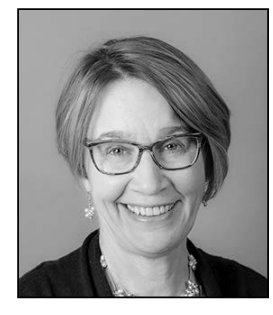

$\mathrm{D}$ $r$ Catherine (Cathy) Cervin was installed as the 67th President of the CFPC on November 6, 2020, as part of Family Medicine Forum.

Dr Cervin grew up in the tiny community of Harrow in southwestern Ontario. A restless teen, she could not wait to leave to explore the world. Yet 2 early adventures would set her on a path leading to a lifelong passion for rural family medicine. Her first chance to expand her horizons came at 16 when her father, a psychologist at the University of Windsor in Ontario, took a sabbatical. Over the course of a year, her family enjoyed months-long stays in the United States, France, England, and Spain.

"I made the decision to go into medicine during that sabbatical year in Europe," she says. "I loved the sciences and loved working with people, and I had a strong sense of social justice from my parents. I thought if I were a doctor then people would pay more attention to what I had to say."

The following year she and 2 friends happened to take a road trip to Sudbury in northern Ontario. Dr Cervin recalls falling in love with the pristine waters and rocky landscapes, where the beauty of Group of Seven paintings is brought to life. At that point, she dreamed of becoming a rural family physician and subsequently attended medical school at the University of Toronto in Ontario.

One of the most formative experiences she had during her training occurred when she spent 2 months in Prince George, BC, working with a physician who was a permanent locum in the area. Dr Cervin gained experience in every department in the local hospital: delivering babies, working in the emergency department, and assisting in the operating room. After a rotating internship in Toronto, Dr Cervin entered the second year of the family residency program at Dalhousie University in Halifax, NS. From there, she turned her sights back to northern Ontario.

Dr Cervin joined the medical community in Timmins, Ont, and found it a great place to start a practice. As she became more aware of local issues and needs, Dr Cervin helped establish a women's health group that organized annual conferences in northern Ontario with speakers from across Canada.

"These conferences were life changing in terms of opening my eyes to global injustices, women's position in the world, and violence against women. This was a time when women's crisis centres and shelters were just getting started. From that time on I had a strong interest in women's health."
By the mid-1980s Dr Cervin was working in Sault Ste Marie in one of Ontario's first family health teams. When she was approached about an academic family medicine position at Dalhousie that included a focus on women's health, Dr Cervin faced a difficult choice. She had a young child and loved her practice, which made uprooting her life challenging, but the draw of academic medicine was irresistible. The family moved to Nova Scotia and Dr Cervin became Chief of the family medicine department of the Grace Maternity Hospital.

In 1997 she was named Director of Dalhousie's family medicine residency program, which marked the beginning of her focus on medical education. That led Dr Cervin to pursue a master's degree in education, and for her thesis she looked at factors that influence family medicine residents' decisions to provide comprehensive care.

The call of the north beckoned to Dr Cervin once again in 2011 when she was asked to join the Northern Ontario School of Medicine faculty as Associate Dean of Postgraduate Education. The opportunity meant she would have to divide family time between Sudbury and Halifax as her partner, Dr David Gass, was tied to the Maritimes through family and his career. The couple made it work, and Dr Cervin is now Vice Dean, Academic at the Northern Ontario School of Medicine. Dr Cervin and Dr Gass now have a blended family with 5 grown children and 4 grandchildren.

Being tapped on the shoulder for leadership roles has been a trend in Dr Cervin's life. Her involvement with the CFPC began in 1997 when she was recruited to the Section of Teachers. She later chaired the Board of Examinations and Certification and the Research and Education Foundation (now the Foundation for Advancing Family Medicine). Dr Cervin joined the CFPC Board of Directors in 2018 and is excited about her term as CFPC President.

"One of the things I've learned over the past few years on the CFPC Board is that one of the President's goals must be supporting members and having members' interests and needs at heart. So, it's not about my personal goals; it's about how I can listen to family physicians in Canada and support and amplify their needs and priorities while also keeping social justice and equity for all Canadians at the forefront." 